\title{
ANDROGENS IN POSTMENOPAUSAL BREAST CANCER: EXCRETION, PRODUCTION AND INTERACTION WITH ESTROGENS
}

\author{
J. H. H. Thussen, J. Poortman* and F. Schwarz \\ Department of Clinical Endocrinology, University Hospital, State University, \\ Catharijnesingel 101, Utrecht, The Netherlands
}

\begin{abstract}
SUMMARY
The role of androgens and estrogens has been investigated in postmenopausal breast cancer patients. No differences were found in the urinary excretion of estrone and of estriol between 41 primary mammary cancer patients and 48 normal postmenopausal women, representative of the normal population. A significantly lower excretion of androgen metabolites (11-DOKS) was found in the patients. Because 11-DOKS in postmenopausal women arise mainly from three secretory products and estrogens are mainly derived from peripheral conversion of androstenedione to estrone, production rates of DHEA, DHEAS and androstenedione and the conversion of androstenedione to estrone were estimated. No significant difference was found between the two groups for the blood production rate of androstenedione, neither for its conversion to estrone. The urinary production rate of DHEAS was definitely lower in the selected breast cancer patients compared to normal controls. The DHEA production rate was also lower but statistical significance was not achieved.

On account of these results the hypothesis was tested that DHEAS, DHEA or one of their metabolites might interfere with the binding of estradiol to its specific receptor, an essential step in its mechanism of action. From the results of an in vitro incubation study of receptors from human myometrial and mammary tumour tissue with several steroids, evidence was obtained that the estradiol binding was inhibited, in a molar concentration ratio not far beyond the physiological range, by 5 -androstene- $3 \beta, 17 \beta$-diol, a steroid closely related to DHEA. If these in vitro findings may be applied to in viuo conditions, it is conceivable that androstenediol is a regulating agent of estrogenic action at the cellular level.
\end{abstract}

\section{INTRODUCTION}

In the epidemiology of breast cancer environmental factors related to nutrition $[1,2]$ as well as hormonal factors $[3,4]$ are thought to play a role. As the hormones in some way involved in the development or growth of malignant mammary tumours, prolactin, progesterone, estrogens and androgens have been implicated.

Despite unequivocal evidence that prolactin stimulates the induction of experimental mammary tumours in rats $[5,6]$ and mice $[7]$, there is little evidence for a relationship between circulating prolactin levels and human breast cancer $[8,9]$. Regarding progesterone, Sherman and Korenman[10] recently have suggested that estrogenic stimulation in the absence of sufficient cyclic progesterone secretion by the corpus luteum, might provide a setting favorable to the development of mammary carcinoma.

\footnotetext{
* Senior Research Fellow of the Dutch Organisation for Cancer Research (Koningin Wilhelmina Fonds).

Abbreviations used: $\mathrm{E}_{1}$-estrone, 3-hydroxy-1,3,5(10)estratrien-17-one; $\quad E_{2}$-estradiol, 1,3,5(10)-estratriene$3,17 \beta$-diol; $\mathrm{E}_{3}$-estriol, 1,3,5(10)-estratriene-3,16 $\alpha, 17 \beta$-triol; DHEA-dehydroepiandrosterone, $3 \beta$-hydroxy-5-androsten-17-one; DHEAS-dehydroepiandrosterone-sulfate; DHT-dihydrotestosterone, $5 \alpha$-androstane-17 $\beta$-ol-3-one; $\mathrm{T}$--testosterone, 4-androstene-17 $\beta$-ol-3-one; $\mathrm{A}$-androstenedione, 4-androstene-3,17-dione; Adiol-5-androstene-

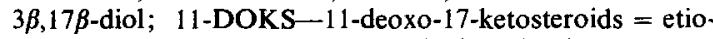
cholanolone + androsterone + dehydroepiandrosterone.
}

It is generally believed that estradiol is an important hormone in the genesis of human breast cancer [3]. Measurements of urinary estrogen excretion however, have not yielded clear evidence for an increase of estrogens in breast cancer patients [11]. Moreover, the recently available blood levels of estradiol and estrone have not shown differences between normal women and patients with mammary carcinoma [12].

The most convincing endocrine abnormality in patients with breast cancer has been found to be a subnormal excretion of 11-deoxy-17-ketosteroids (11-DOKS) in patients before the menopause [1318]. In a prospective study on women younger than 50 years, low excretion of 11-DOKS has been found in a large proportion of those in whom the malignant tumour was detected several years later [4]. In addition to these data on urinary excretion, the plasma levels of DHEAS have been found to be lower in breast cancer patients than in healthy women $[19,20]$.

This paper will deal with androgens and estrogens in human breast cancer in women after the menopause. Three aspects will be considered.

1. Urinary steroid excretion in primary breast cancer patients and in a control group, chosen as to be representative of the normal population.

Because in postmenopausal women androgen metabolites in the urine arise mainly from three secretory products, and estrogens are mainly derived 
from peripheral conversion of androstenedione to estrone, we studied:

2. The urinary production rate of DHEA and of DHEAS, the blood production rate of androstencdione and the extent of conversion of circulating androstenedione into estrone in a group of selected breast cancer patients and in normal postmenopausal women.

On account of the results obtained, the possibility was considered that the production of DHEAS and of DHEA might in some way be related to the development or to the growth of mammary tumours. In a recent article Swain et al.[21] wrote: "It would be tempting to suppose that estrogenic and progestational stimuli to the breast are modified by androgen secretion and that deficiencies in androgen production lead to an abnormal stimulus to breast tissue by plasma levels of estradiol and progesterone that are within the normal range".

Because the binding of estradiol to a specific receptor is necessary for its action, the hypothesis was tested:

3. that DHEAS, DHEA or one of their metabolites might interfere with the binding of estradiol to its specific receptor. This problem was investigated by in vitro incubation of human myometrial and mammary cancer tissue with several steroids. As a metabolite of DHEA, which might be of significance, 5 -androstene- $3 \beta, 17 \beta$-diol (adiol) was chosen. This weak androgen is present in the plasma of fertile women in a concentration of $60-90 \mathrm{ng} / 100 \mathrm{ml}$ [22]. Circulating DHEA accounts for one-third of the total adiol production [23]. As the presence of a specific DHT-receptor in human mammary tumour tissue has been demonstrated [24], the interaction of steroids with this receptor has heen included.

\section{EXPERIMENTAL}

\section{Subjects}

Urinary steroid excretions were studied in normal postmenopausal women (age limits 55-75 yr) taking part in a prospective study on breast cancer, designed by de Waard in the Netherlands ("Kamperfoelie or Honeysuckle" project). Out of the 7500 women in this study, a small control group was selected, representative of the normal population. In this group the age was $65 \cdot 0 \pm 5 \cdot 2$ (S.D.) yr.

The breast cancer patients group consisted of 41 out of the first 50 women who developed breast cancer during the study. Urine was collected some months after primary treatment while the patients were in good general condition and without signs of recurrence. They received no hormonal treatment. The age of this group was $63.9 \pm 5.5 \mathrm{yr}$.

Androgen production rates were studied in 16 normal volunteers, who were hospitalized for minor complaints. They were ambulatory, had good cardiac, hepatic and renal function; there was no evidence of endocrinological or gynecological disease. Spontaneous menopause had occurred at least 4 years before the investigation. The mean age was $59 \cdot 6 \pm 8 \cdot 2 \mathrm{yr}$

The seven breast cancer patients studied were selected according to the following criteria:

(a) At the time of the operation of the breast tumour, all patients were at least $6 \mathrm{yr}$ after their spontaneous menopause and at the time of our study at least 3 yr after the operation;

(b) There were no demonstrable metastases at the time of the operation nor at the time of the investigation;

(c) No irradiation or cytostatic treatment had been given, they had not received hormonal therapy;

(d) No endocrine ablations had been performed;

(e) All patients were in good general health at the time of the investigation.

The mean age of these patients was $68 \cdot 3 \pm 8 \cdot 3 \mathrm{yr}$. Informed consent was given by all subjects studied.

\section{MATERIAL AND METHODS}

Urinary analysis was done on $24 \mathrm{~h}$ specimens stored at $-20^{\circ} \mathrm{C}$ without preservative. 11-deoxo-17ketosteroids (=etiocholanolone + androsterone + dehydroepiandrosterone) were estimated as described previously [25].

Estrone and estriol in urine were determined with a specific gaschromatographic method [26]. Estradiol was not measured since its contribution to the total excretion of the three "classical" estrogens in postmenopausal women is small: $8 \%$ on the average [25].

The urinary production rates of DHEA and of DHEAS were measured by isotope dilution techniques after a single intravenous injection of $\left[{ }^{3} \mathrm{H}\right]$ DHEA and of $\left[{ }^{14} \mathrm{C}\right]$-DHEAS. The blood production rate of androstenedione and the extent of its conversion to estrone were estimated by the in vivo internal standard technique, as first described by MacDonald et al.[27]. The details of the methods used have been described recently [28].

The interaction with specific cellular receptors has been investigated by in vitro incubations of human myometrial and mammary cancer tissue with several steroids. The fresh material was frozen in liquid nitrogen and then homogenized with a Microdismembrator (Braun, Melsungen, Germany). A highspeed supernatant was prepared according to the protocol of the E.O.R.T.C., Breast Cancer Cooperative Group[29]. Incubations were carried out with $\left[{ }^{3} \mathrm{H}\right]$-estradiol, in concentrations between $10^{-10}$ and $3 \times 10^{-9} \mathrm{M}$, and with $\left[{ }^{3} \mathrm{H}\right]-\mathrm{DHT}$ in the same concentration range. The competing steroids were dissolved in $25 \mu \mathrm{l}$ of cthanol, diluted with $475 \mu \mathrm{l}$ of $0.01 \mathrm{M}$ Tris-buffer $\mathrm{pH} 7.5$ and $500 \mu \mathrm{l}$ of the supernatant were added. The techniques used are being published in detail elsewhere [30]. 
Excretion in postmenopausal women

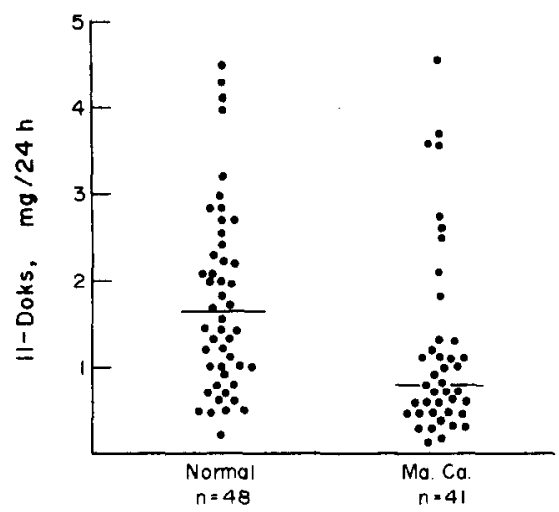

Fig. 1. Urinary excretion of 11-DOKS in normal postmenopausal women and in patients with breast cancer. The median excretion in each group has been indicated by a solid line

\section{RESULTS}

\section{Urinary steroid excretion}

The excretion of 11-DOKS and of estrone and estriol have been estimated in normal postmenopausal women and in patients with primary breast cancer. The median excretion of 11-DOKS (Fig. 1) was in the normal group $1.6 \mathrm{mg}$ and in the cancer group $0.8 \mathrm{mg} / 24 \mathrm{~h}$. In the breast cancer group $60 \%$ excreted less than $1 \mathrm{mg} / 24 \mathrm{~h}$ of $11-\mathrm{DOKS}$, in the control group only $25 \%$ of the values found were below this limit. The difference is significant at the level of less than 0.005 (median test for two samples [31]).

There was no difference between the two groups in the excretion of estrone, the median excretion in both groups was $1.7 \mu \mathrm{g} / 24 \mathrm{~h}$. Regarding estriol, a higher excretion was found in a few patients, but the median values were again identical in both groups: $3 \cdot 1 \mu \mathrm{g} / 24 \mathrm{~h}$ (Fig. 2).

\section{Production and conversion rates}

In eight normal subjects and in seven patients, who had been operated for mammary carcinoma, the metabolic clearance rate and the blood level of androstenedione were measured. Results are given in Table 1, together with the calculated blood production rates of androstenedione. According to the techniques as described by MacDonald[27], the extent of conversion of circulating androstenedione to estrone was estimated and the amount of estrone resulting from this conversion was calculated.
Excretion in post menopausal women

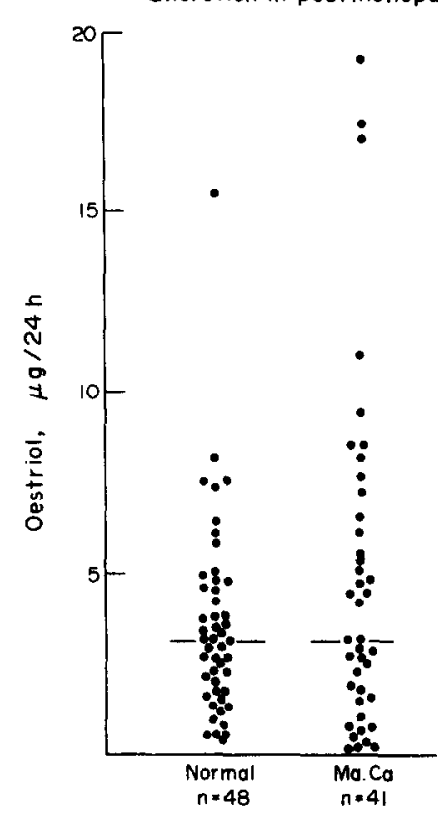

Fig. 2. Estriol excretion in normal postmenopausal women and in patients with mammary carcinoma. The median excretion in each group has been indicated by a solid line.

The metabolic clearance rate of androstenedione is higher and the plasma level is lower in the cancer group than in the normal women. These differences are statistically not significant. The conversion of androstenedione to estrone is similar in both groups as is the resulting production of estrone.

Our data on the urinary production rates of DHEAS and of DHEA are illustrated in Fig. 3 for both groups. The production rate of DHEAS found in the breast cancer group is significantly lower than that in the normal postmenopausal women (Wilcoxon test, $P<0.025)$. The difference observed in the production rate of DHEA is not significant $(P=$ $0.1)$.

Interaction with estradiol and dihydrotestosteronereceptors

Our findings on the inhibition of the specific binding of estradiol and of DHT by several steroids are shown in Tables 2 and 3 . In these tables the percentage of binding inhibition for the steroids tested is calculated with reference to the inhibition obtained with nafoxidine (U 11.100) in a molar conconcentration ratio of 1000 for estradiol binding, resp.

Table 1. Metabolic clearance rate (MCR), plasma concentration and blood production rate of androstenedione, its conversion to estrone and the production of estrone resulting from this conversion in normal postmenopausal women and in selected breast cancer patients

\begin{tabular}{|c|c|c|}
\hline & $\begin{array}{l}\text { Normal women } \\
\quad(n=8)\end{array}$ & $\begin{array}{l}\text { Breast cancer patients } \\
\qquad(n=7)\end{array}$ \\
\hline $\begin{array}{l}\operatorname{MCR}^{A}(1 / 24 h) \\
\operatorname{Plasma-level}^{\wedge}(\mu \mathrm{g} / \mathrm{l}) \\
\text { Production rate }(\mathrm{mg} / 24 \mathrm{~h}) \\
\text { Conversion } \mathrm{A} \rightarrow \mathrm{E}_{1}(\%) \\
\mathrm{E}_{1} \text { derived from } \mathrm{A}(\mu \mathrm{g} / 24 \mathrm{~h})\end{array}$ & $\begin{array}{c}1843 \pm 131 \\
0.83 \pm 0.13 \\
1.64 \pm 0.38 \\
2.5 \pm 0.3 \\
\text { ca. } 40\end{array}$ & $\begin{array}{c}2398 \pm 425 \\
0.56 \pm 0.12 \\
1.46 \pm 0.39 \\
2.9 \pm 0.2 \\
\text { ca. } 40\end{array}$ \\
\hline
\end{tabular}



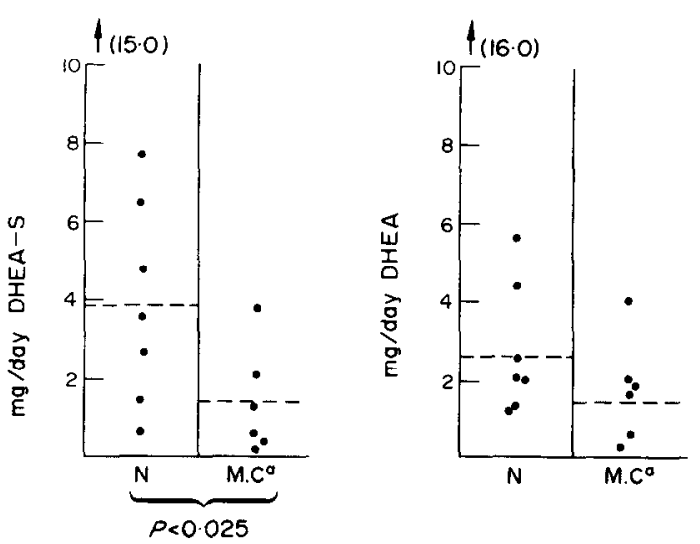

Fig. 3. The urinary production rates of DHEAS and of DHEA resp. in 8 normal postmenopausal women and in 6 selected breast cancer patients. The mean production is indicated by a broken line (-- ).

with cyproterone acetate in a ratio of 10,000 for DHT.

The inhibiting power of adiol on the estradiolbinding, in myometrial as well as in malignant tumour tissue, was much greater than that of testosterone or of DHT at the same molar concentration ratio. With regard to the DHT-binding, adiol is more active than estradiol and less active than testosterone.

It can be calculated (Fig. 4) that a $50 \%$ inhibition of estradiol-binding required a molar concentration of about 40 for adiol, of more than 2000 for testosterone and DHT and of about 20,000 for DHEA. No significant inhibiting activity could be found for androstenedione up to a molar concentration ratio of 10,000 and for DHEAS up to 40,000 . The inhibiting power of adiol is close to that of nafoxidine in similar molar concentrations [33].

\section{DISCUSSION}

The overall picture that emerges from our findings is in general agreement with data reported in the literature. It consists of equality between postmenopausal breast cancer patients and the control group in estrogen production and excretion, but differences

Table 2. Myometrial and mammary tumour extracts were incubated with $\left[{ }^{3} \mathrm{H}\right]$-estradiol, concentration $5 \times 10^{-11}$ to $10^{-9} \mathrm{M}$, in the presence of several potential inhibitors

\begin{tabular}{|c|c|c|c|c|c|}
\hline \multirow[b]{2}{*}{$\begin{array}{l}\text { Inhibiting } \\
\text { compound }\end{array}$} & \multirow{2}{*}{$\begin{array}{l}\text { Molar ratio } \\
\text { inhibiting } \\
\text { compound/ } E_{2}\end{array}$} & \multicolumn{2}{|c|}{ Myometrium } & \multicolumn{2}{|c|}{ Tumour } \\
\hline & & $\begin{array}{l}\text { Number of } \\
\text { experiments }\end{array}$ & $\begin{array}{c}\text { Inhibition } \\
\text { mean } \pm \text { S.E.M. }\end{array}$ & $\begin{array}{l}\text { Number of } \\
\text { experiments }\end{array}$ & $\begin{array}{c}\text { Inhibition } \\
\text { mean } \pm \text { S.E.M. }\end{array}$ \\
\hline Nafoxidine & 1000 & 15 & 100 & 16 & 100 \\
\hline Estradiol & 100 & 5 & $102 \pm 1$ & 5 & $104 \pm 2$ \\
\hline Testosterone & 100 & 4 & $22 \pm 7$ & 3 & $16 \pm 8$ \\
\hline DHT & 100 & 4 & $17 \pm 1$ & 3 & $10 \pm 5$ \\
\hline DHEA & 40,000 & 3 & $74 \pm 5$ & -.. & - \\
\hline DHEAS & 40.000 & 1 & 28 & & \\
\hline Adiol & 6 & 6 & $14 \pm 3$ & - & - \\
\hline Adiol & 10 & 3 & $14 \pm 3$ & 3 & $17 \pm 5$ \\
\hline Adiol & 30 & 8 & $33+8$ & 2 & 45 \\
\hline Adiol & 60 & 6 & $44 \pm 4$ & 1 & 59 \\
\hline Adiol & 100 & 12 & $57 \pm 5$ & 5 & $62 \pm 4$ \\
\hline Adiol & 200 & 13 & $72 \pm 5$ & 1 & 73 \\
\hline Adiol & 1000 & 2 & 100 & 1 & 105 \\
\hline
\end{tabular}

The concentration of these steroids is expressed as molar ratio to the $\left[{ }^{3} \mathrm{H}\right]$-estradiol. The inhibition of the binding of $\mathrm{E}_{2}$ to its receptor is calculated as a percentage of the decrease of the specific binding caused by nafoxidine $(1000 \times)$.

Table 3. Myometrial and mammary cancer extracts were incubated with $\left[{ }^{3} \mathrm{H}\right]$-dihydrotestosterone (DHT), concentration range $10^{-10}$ to $10^{-9} \mathrm{M}$, in the presence of several potential inhibitors

\begin{tabular}{|c|c|c|c|c|c|}
\hline \multirow[b]{2}{*}{$\begin{array}{l}\text { Inhibiting } \\
\text { compound }\end{array}$} & \multirow{2}{*}{$\begin{array}{c}\text { Molar ratio } \\
\text { inhibiting } \\
\text { compound/DHT }\end{array}$} & \multirow{2}{*}{$\begin{array}{l}\text { Myometrium } \\
\text { Number of } \\
\text { experiments }\end{array}$} & \multirow[b]{2}{*}{$\begin{array}{c}\text { Inhibition } \\
\text { mean } \pm \text { S.E.M. }\end{array}$} & \multicolumn{2}{|c|}{ Tumour } \\
\hline & & & & $\begin{array}{l}\text { Number of } \\
\text { experiments }\end{array}$ & $\begin{array}{c}\text { Inhibition } \\
\text { mean } \pm \text { S.E.M. }\end{array}$ \\
\hline $\begin{array}{l}\text { Cyproterone } \\
\text { Acetate }\end{array}$ & 10,000 & 15 & 100 & 13 & 100 \\
\hline DHT & 100 & 7 & $100 \pm 1$ & 2 & 100 \\
\hline$T$ & 100 & 1 & 95 & 1 & 95 \\
\hline Estradiol & 100 & 2 & 66 & 1 & 52 \\
\hline Adiol & 10 & 2 & 35 & 1 & 49 \\
\hline Adiol & 30 & 1 & 59 & 1 & 74 \\
\hline Adiol & 60 & 1 & 73 & 1 & 82 \\
\hline Adiol & 100 & 8 & $81 \pm 3$ & 3 & $81 \pm 5$ \\
\hline Adiol & 200 & 1 & 89 & 1 & 92 \\
\hline
\end{tabular}

The concentration of these steroids is expressed as molar ratio in relation to the molarity of the tritiated DHT. The inhibition of the binding of DHT to its receptor is expressed as a percentage of the decrease of specific binding, estimated from incubations with and without cyproterone acetate $(10,000 \times)$. 


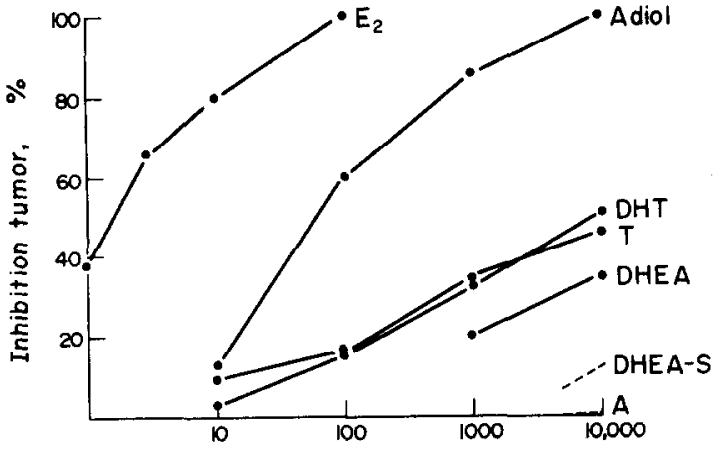

Molar ratio compound $/ E_{2}$

Fig. 4. Inhibition of estradiol-binding to its specific receptor from mammary tumours by several naturally occurring steroids. The molar ratio of these steroids in relation to the molarity of $\left[\mathrm{H}^{3}\right]$-estradiol is expressed on a log scale. The percentage of inhibition is calculated with reference to the inhibition obtained with nafoxidine (U. 11,100), a specific inhibitor of estradiol binding to its receptor, in a molar concentration ratio of 1000 .

regarding the production and excretion of 11-deoxoandrogens. If the steroid-hormonal environment is involved in the causation or in growth control of human breast cancer, the mechanism of its action must very probably be sought in the balance betwcen androgen and estrogen action. We have been looking for the effect of this balance at the level of estradiol-binding to specific receptors in target cells, a binding which is an essential step in the mechanism of action of the hormone.

There appears to exist a competition for receptor binding sites between estradiol and 5-androstene$3 \beta, 17 \beta$-diol. Further work (to be published) demonstrated that other related $3 \beta, 17 \beta$-dihydroxy steroids as $5 \alpha$-androstane- $3 \beta, 17 \beta$-diol show similar, but somewhat weaker inhibitory activity. These compounds are (partly) derived from DHEA and DHEAS. Their plasma levels will be dependent on the production rate of their precursors and will very probably be decreased by diminished production of them. Even when estrogen production is not increased, at the cellular level the balance of action will then shift to enhanced estrogenicity.

Estradiol levels in fertile women range between 4 and $40 \mathrm{ng} / 100 \mathrm{ml}$ [32-34], levels of adiol range between 60 and $90 \mathrm{ng} / 100 \mathrm{ml}$ [22]. In our in vitro experiments adiol inhibited estradiol-binding by $50 \%$ in a molar concentration ratio of $40: 1$. Already at molar ratios of 6 and 10 some inhibiting activity could be demonstrated (Table 2). If these figures may be applied to in vito conditions, it is conceivable that adiol might be a regulatory agent of estrogen action, even in fertile women. It must be realized that tumour growth is a process of many years duration and that therefore even small changes may suffice for a decisive biological effect.

In postmenopausal women plasma estradiol is as low as $1 \mathrm{ng} / 100 \mathrm{ml}$ [35]; we do not know yet the level of adiol in this age group. There is a fair chance of it being high enough to account for an effective inhibitory action.

At least two other hypotheses, concerning hormonal balances in human breast cancer, deal with estradiol on one side and steroids opposing its stimulatory activity on the other.

Cole and MacMahon[36] called attention to the urinary estriol/estrone + estradiol quotient. In an attempt to understand the protective action against breast cancer of a so called early first pregnancy, they suggested that estriol might protect against the stimulatory activity of estradiol. They since have published figures on the quotient [37], measured in young non-pregnant females from several countries with a large difference in breast cancer incidence. The data reported are concordant with their hypothesis. A similar hypothesis has been proposed by Lemon and Wotiz $[38,39]$ on the basis of animal experiments. The question arises however, whether the findings on urinary estrogens reflect the levels of these steroids in blood or in tissue cells [40]. Moreover, estriol blood levels are extremely low in non-pregnant women [41].

Sherman and Korenman[10] suggested that the stimulatory activity of estrogens might be opposed by progesterone in the normal female. In subjects with an inadequate corpus luteum function, the absence of an adequate progestational phase may provide a hormonal setting in the mammary gland favorable to the development of carcinoma. There are no data as to the mechanism of this proposed antagonism.

Our hypothesis on the significance of adiol is supported by the in vitro data reported here. It needs further investigations on the production rate, blood level and metabolism of adiol in cancer patients and in normal women. Furthermore the biological properties of adiol itself will have to be studied. If adiol is bound by the receptor and is transported into the nucleus, we do not know what action it there exerts. Studies in these directions are in progress.

There remains the question whether these data add to our understanding of endocrine therapy in mammary cancer. The results shown here do not account for the therapeutic action of the commonly used androgens. These compounds have a 3-ketoconfiguration and therefore their inhibition of estradiol-receptor binding is weak. It may be that in this respect the presence of specific androgen receptors is of importance. But nothing is known yet about the relation of these receptors to the results of endocrine therapy.

Acknowledgements--The authors are very grateful to Prof. F. de Waard for his collaboration. The excellent technical assistance of Miss W. Veeman, Mrs. D. Vroegindewey and Mrs. M. Zaunbrecher has been of great value for our study. Specimens of uteri were obtained via the kind cooperation of the Gynecological Departments of the "Diakonessenhuis" and the University Hospital in Utrecht; tumour samples via the Surgical Departments 
of the "Diakonessenhuis", "Oudenrijn Ziekenhuis", "St. Antonius Ziekenhuis" and the University Hospital in Utrecht, the Netherlands. Part of this study was supported by the Netherlands Organization for Fundamental Research (FUNGO).

\section{REFERENCES}

1. Hems G.: Brit. J. Cancer 24 (1970) 226-234.

2. Wynder E. L.: In The Human Adrenal Gland and its Relation to Breast Cancer (Edited by A. P. M. Forrest and P. B. Kunkler). Williams and Wilkins Co., Baltimore (1968) pp. 32-49.

3. MacMahon B. and Cole Ph.: J, natn. Cancer Inst. S0 (1973) 21-42.

4. Bulbrook R. D., Hayward J. L. and Spicer C. C.: Lancet ii (1971) 395-398.

5. Boyns A. R., Buchan R., Cole E. N., Forrest A. P. M. and Griffiths K.: Eur. J. Cancer 9 (1973) 169-174.

6. Pearson O. H., Murray R. L. M., Mozaffarian G. and Griffiths K: In Prolactin and Carcinogenesis (Edited by A. R. Boyns and K. Griffiths). Alpha Omega Alpha Publishing Co., Cardiff (1972) pp. 154 161.

7. Boot L. M.: Induction by prolactin of mammary tumours in mice, Noord-Hollandse Uitgevers Maatschappij (1969).

8. Wilson R. G., Buchan R., Roberts M. M., Forrest A. P. M., Boyns A. R., Cole E. N. and Griffiths K.: Cancer 33 (1974) 13251327

9. Kwa H. G., de Jong-Bakker M., Engelsman E. and Cleton F. J.: Lancet i (1974) 433-435.

10. Sherman B. M. and Korenman S. G: Cancer 33 (1974) 1306-1312.

11. Hayward J. L.: Hormones and Human Breast Cancer, An Account of 15 Years' Study. Springer Verlag, Berlin-Heidelberg-New York (1970).

12. Swain M. C.: Acta endocr. Copenh. suppl. 177 (1973) 29.

13. Bulbrook R. D., Hayward J. L. and Thomas B. S.: Lancet i (1964) 945-948.

14. Bulbrook R. D., Greenwood F. C. and Hayward J. L.: Lancet i (1960) 11541157.

15. Kumaoki S., Sakauchi N., Abe O., Kusama M. and Takatani O.: J. clin. Endocr. Metab. 28 (1968) 667-671.

16. Miller H. and Durant J. A.: Clin. Biochem. 1 (1968) 287-298.

17. Cameron E. D. H., Griffiths K., Gleave E. N., Stewart H. J., Forrest A. P. M. and Campbell H.: Brit. Med. $J$. iv (1970) 768-771.
18. Argüelles A. E., Poggi U. L., Saborida C., Hoffman C. Chekherdemian M. and Blanchard O.: Lancet i (1973) $165-168$.

19. Brownsey B., Cameron E. H. D., Griffiths K., Gleave E. N., Forrest A. P. M. and Campbell H.: Eur. J. Cancer 8 (1972) 131-137.

20. Wang D. Y. and Herian M.: Acta endocr. Copenh. suppl. 177 (1973) 30.

21. Swain M. C., Hayward J. L. and Bulbrook R. D. Eur. J. Cancer 9 (1973) 553-556.

22. Rosenfield R. L. and Otto P.: J. clin. Endocr. Metab. 35 (1972) 818-822.

23. Kirschner M. A., Sinhamahapatra S., Zucker I. R., Loriaux L. and Nieschlag E.: J. clin. Endocr. Metab. 37 (1973) $183-189$.

24. Wagner R. L., Görlich L. and Jungblut P. W.: Acta endocr. Copenh. suppl. 173 (1973) 65.

25. Thijssen J. H. H.: In 18th Yearbook of Cancer Research in the Netherlands (Edited by J. H. de Bussy). Amsterdam (1968) pp. 171-183.

26. Thijssen J. H. H. and Veeman W.: Steroids 11 (1968) 369-387.

27. MacDonald P. C., Rombaut R. P. and Siteri P. K. J. clin. Endocr. Metab. 27 (1967) 1103-1111.

28. Poortman J., Thijssen J. H. H. and Schwarz F.: $J$ clin. Endocr. Metab. 37 (1973) 101-109.

29. E.O.R.T.C. Breast Cancer Cooperative Group, Eur. J. Cancer 9 (1973) 379-381.

30. Poortman J., Prenen J. A. C., Schwarz F. and Thijssen J. H. H.: J. clin. Endocr. Metab. $\mathbf{4 0}$ (1975) 137-143.

31. Dixon W. J. and Massey F. J., Introduction to Statistical Analysis McGraw-Hill Book Company, Inc.. New York-Toronto-London (1957) pp. 295-296.

32. Mikhail G., Wu C., Ferin M. and VandeWiele R. L.: Steroids 15 (1970) 333-352.

33. Abraham G. E., Odell W. D., Swerdloff R. S. and Hopper K.: J. clin. Endocr. Metab. 34 (1972) 312-318.

34. Dupon C., Hosseinian A. and Kim M. H.: Steroids 22 (1973) 47-61.

35. Rader M. D., Flickinger G. L., deVilla G. O., Mikuita J. J. and Mikhail G.: Am. J. Obstet. Gynecol. 116 (1973) 1069-1073.

36. Cole Ph. and MacMahon B.: Lancet i (1969) 604-606.

37. MacMahon B., Cole Ph., Brown I. B., Aoki K., Ming Lin T., Morgan R. W. and Woo N. C.: Lancet ii (1971) 900-902

38. Lemon H. M., Wotiz H. H., Parsons L. and Mozden P. J.: J. Am. Med. Ass. 196 (1966) 112-120.

39. Lemon H. M.: J. Surg. Oncol. 4 (1972) 255-273.

40. Lipsett M. B.: Lancet ii (1971) 1378

41. Longcope C.: Annual Program Review Conference Breast Cancer Task Force, Denver (1974) p. 6. 